\title{
Dagbog-Optegnelser fra Krigen 1864.
}

\author{
Af J. Raben.
}

Gaardejer Henrik P. Hansen, Trovshøjgaard paa Dybbol Mark, født paa Nørremølle den 21. Marts 1823, død paa Trovshøjgaard den 18, April 1916, har i 1864 ført en Dagbog under Titlen: "Dagbog fra den Tid, vi drog fra Dybbøl«.

Bogen ejes af Sønnen, Købmand Hans P. Hansen i Sønderborg. Foruden Optegnelser vedrørende Familien og om Landbrugisarbejde o. a. indeholder Dagbogen en Mængde Notitser om Indkvartering og militære Begivenheder, der ikke or uden Interesse.

Optegnelserne begynder den 6. Februar 1864, da de første danske Tropper kom tilbage fra Dannevirke. Samme Dag begyndte han at rømme sin Gaard, der kun ligger smaa 200 Meter vest for Skanse III. Indboet blev kørt dels til Nørremølle, dels til Snogbæk.

Familien tog den 7. Februar først til Nørremølle, den 9. Feloruar flyttede de til Mattesens Bol i Snogbæk, ${ }^{1}$ ) hvor de blev til den 23. August. Trovshøjgaard var da atter genopbygget efter Branden og saavidt færdig, at Familien kunde flytte tilbage til Uybbøl Mark.

\section{Dagbogen.}

1864.

\section{Februar.}

6. - »Idag begyndte vi at flytte vort Tøj fra Hjemmet til Nørremølle og Snogbæk. Broder Christen ${ }^{2}$ ) kom over, men gik straks igen for at faa Vogne til Tøjet.

1) "Mattesens Bol" laa lidt nord for Nørremølle or hørte til samme Ejendom.

${ }^{2}$ ) Christen Hanssen, Nørremølle, H. P. Hanssens Fader. 
7. - Vi fik det meste Tøj bort, som ogsaa vi med de mindste Børn og de to unge Heste drog bort. Om Aftenen lod Broller vore Køer samt et Ixs Tøj, for det meste Sengetøj, afhente.

8. - Opholdt vi os enclnu i Nørremølle. Jeg var en Tur hjemme og fik Hans til Nørremølle med de to Heste, og et Læs Tøj, som var det sidste vi fik. Jeg tog P. Vogd's rle sirlste Kwer med, ren 8 . kom Vogds ogsaa til Nørremølle.

9. - Flyttede vi op til Mattesen, Christen og Jacol, kom til Svoger Hans Jørgen, Anna og Iorthe blev i Nørremølle.

Fra den 9. til 18. leverle vi roligt hos Mattesen, men der bræudte ikke saa faa Steder i Dybbol, men dog af dem, som laa foran Skanscrne, deriblandt ogsaa vor Gaard, son vistnok brændte den 18. Feloruar. Da kom ogsaa de første store tyske Patrouiller hertil, af hvilke mange var inde hos os. Ilag har cle taget Pastor Bülow og Inspektoren til Fange.

19. - Her var tre Mand on Morgenen, store Patrouiller er gaget forbi. Orn Aftenen kom igen tre Mand.

20. - Var vi fri for Patrouiller. Om Aftenen kom tre Mand ind til os, den ene var fuld, Broder Christian var lier og tog dem med lijem til sig.

21. - Sønclag. Irlag var vi fri for Patrouiller. Jeg og Moder fulgtes ad til Norremolle for at gratulere til Konfirmation og Hans Peters ${ }^{1}$ ) Fodselsrlag. De sloges igen verl Forposterne, som de havde gjort i de sidste. Dage, og der kom her forbi en Dod og en Saaret. I Dyl)hol brænilte det igen et Sted. Gud ved, om det ikke var P. Vogrk. V. H. st. (d. $\left.{ }^{2}\right)$

22. - Idag hørte vi at det var $H$. Hunssens (dler var brendt (l. 20.). Om Morgenen tiıllig kom en stor Patrouille med to Kanoner og greb Forposterne an. De brændte Sanrlbjerg Vejrmelle af og toge nogle llanske til Fange.

23. - Der var 6 Dragoner inde i Gaarden, men de rede straks igen. Vi fik vort Flæsk i Røg.

24. - Om Eftermiddagen Kl. 3 kom en stor Patrouille forbi, da den kom tilbage, var en Officer inde i Gaarden og fik et Glas Vand. De havde kørt deres Medicinsvogn itu.

:5. - Der brændte flere Steder i Dybbøl, det er sikkert alle den ved Chausséen fra Frydendal til Bøffelkobhel.

1) H. P. Hanssen-Nølremølle, født 21. Februar 1862.

2) Skal betyde: "Vor Herre straffe dem". 
26. - Imorges var her to Inagoner, som vilcle have Kaffe. men fik ingen Tirl. Der var gaaet to Patrouiller forbi. Den fxrste kom tilhage med 5 Fanger eller Overlølere, og to Overlobere val her og spurgte Vej til Flensborg. Broder Jørgen har faat Ordre til at rrmme Huset, som tillige hele Rageløl By. Gud give det ikke mat ske! Det brændte igen i Iyblogl, men der var tykt i Vojret og ikke noget at se. Iet brændte hele Natten.

27. - Branden den 21de var hos Jørgen Marcussens. Om Morgenen gik jeg til Nøıremølle; da jeg kom til J. Jensens Lerl, stod Brodler Jørgens Hus i lys Lue.") En stor Patrouille kom om Eftermidlagen ad Aushoj-Vejen. Om Aftenen, da jeg var gaaet i Seng, kom tre Mand og spurgte om Vej. - Alle Huse ved Sundet ved Smderhorg skulle ogsaa vare borte.

2x. - Sondag. Gud give, at lemne l'ge ikke maa blive saa raxlselsfuld som sidste ITge, og lad begge Parter snart enes om en lykkelig Fred! - Denne Dag gik, Gud vare lovet, hen urlen markelige Begivenheler. Her kom blot en Projser, som fik Smørrebror.

2!. - Eftor Bloder Christens Efterretninger gik det ikke bedre igaar. 1)er lramlte et Sted pan Stenderupmose, og de havile nær skult Manden. De vare i Sottrup igaar for at fourere efter Straa og Brande, men toge ogsaa Kartofler, Flæsk og Havre. Idag var de her, men (ie var rimelige. De fik 21/2 Trave Klap og ingen Favnelræncle. I Aften havie de Danske et stort Blus pa Skanserne.

\section{Marts.}

1. - I)en Dag gik rolig hen for os. De sloges igen verl Forposterne of: der brandte vistnok igen paa Stenderupmose. lisse Huse skulle alle være horte.

2. - Imorges var her fire som fik Smørrebrol. De fortalte, at deres Folk havde besat Stenderup og Nybol i Nat, thi de lanske vilde brænde Byerne af. Men dette var vel nok ikke Grunden, thi i Middags kom der mange forbi med den hele Oppakning, som de ellers aldrig har paa, livoraf jeg straks dømte, at de vilde flytte Kaden. Hen paa Eftermidlagen kom ogsaa deres hele Bagage og cle fik Indkvartering her i Snogbæk. Broder fik Ordre at tage imod 1\$0 Mand med 5 officerer, men da de havde deres Mad paa Ilden, kom der igen Ordre, at bringe deres Mad til Sottrup. Vi slap endnu i Dag.

3. - Idag var alting rolig og stille her. Vi fik ingen Inclkvartering, og Broder heller ingen. Prøjserne forskanser sig starkt ved Sottrup i Dag.

1) Jørgen Hansens Gaard i Ravnskobbel. 
4. - Imolges kørte Hans i Krigskørsel til Flensiborg. Alle de Sottruper Smaafolk var paa Skansearbejde i l)ag hos Projserne og skal igen paa Arhejole i Morgen.

5. - Hans kom hjem idag fm Flensborg og havde et Las Vurer med.

6. - Søndag. Idag er vor Jens paa Krigskorsel til Flenshorg, Mathias paa Skansearbejde. Broder Jølgen er kølt til Flenshorg efter Varer for Christen. Han solgte idag 27 Køer til Slagter Paulsen. Mod Aften kom 2 Dragoner her ind, de fik Kaffe og 2 Punl Flask, men havde ingen Penge irlag.

7. - Idag fik vi 44 Mand af 15. Regiment med 2 Løjtnanter, 1 Felıwebel, to Inderofficerer og to Foermænd fra Bovrup. Jens kom hjem fra Krigskørsel, Brorler Jørgen kom ogsaa tilhage fra Flensborg.

8. - Samme Indkvartering. De (Prøjserne) forskanser sig ved Broder Christen. Vor Vogn kørte til Aabenraa.

9. - Idag kom den anden Vogn bort; første kom lijem og den ene Hest var syg; den havile ogsaa veret i Flensborg.

10. - Idag kom den sidste Vogn hjem, den havde varet i Sottrup og kint verl Forposterne.

11.-12. - Ikke noget af Interesse.

1:3. - Idag brændte det igen nogle Steder, nemlig P. Johansens, J. Jers, J. Moos og paa Stenderup Mose.

16. - Iclag lirwndte sikkert Paul Paulsens og Philipsens Steder paa l)ybbøl. Endnu samme Indkvartering.

17. - I Middags fik de (Indkvarteringen) Ordre til at rykke ud. De skulde paa Forpost, men de Danske greb an forinclen. Husene i Baadslund og Staugaard blev brændt af og vist et eller to i Stende. rup. Om Eftermiddagen brændte Randersgaard og flere Steder i nybbøl, om Aftenen flere Steder i Ragebøl og maaske H. P. Jahnsens. Der var en haard Kamp den hele Eftermiddag, baade med Cieværer og Kanoner. Vol'e kom igen hen paa Aftenen og blev til K. 12, da droge de bort og vi havde ingen i Nat.

18. - Om Aftenen kom her igen 70 Mand af 55. Regiment med to Officerer. Vi maatte koge Kaffe til dem. De var saare gode. I Eftermiddag skød de igen fra Skanserne, men vist uden Resultat.

19. - Samme Indkvartering. Vi fik i Formiddags 6 Heste og 3 Mand, de drog dog straks videre. Der blev skudt paa og fra Skanserne. 
:0. - Sondag. Indkvarteringen, undtagen tre Mand var om Eftermiddagen paa Skansearbejde. De kom hjem igen K1. 2 om Natten. Der blev skudt med Kanoner paa begge Sider.

21. - Om Eftermiddagen kom Indkvartering lort, vi fik igen 60 Mand og 2 Officerer af 15 . Regiment.

22. - Samne Indkvartering; de er ikke gode. Mathias maatte kare efter Levnedsmidler for dem, om Aftenen matte han kqre en Marketenderske til Kasmusmolle.

24. - Skartorsdag.

25). - Langfredag.

26. - Jeg var til Broager og gik over Dybbøl hjem. Der var det ingen Fornujelse at komme; jeg var hos Svoger Vogd's, men det saa slemt urt. Der laa en Prøjser begravet i Vejkastet twet ved Bakkehuset. J. Marcussens, (ved Frydendal), J. Andersens, L. Tyksens, $\therefore$ Norhalles, Smerlens, Thysens, (i I)ybbøl By), Lie, J. Mikkelsens, (Dybbol), Hvilhøj, Ny Frydendal, C. Smeds (I)yblogllund), er brandte. Jen nedre Ende af Byen, nemlig J. Mollers, N. Bruns, H. Kirkemands (') Kryhlmands er nerlbrudte. 1 '. Staarlsens (rlen yngere) er ogsa liranclt. P. Jensens (Langdamsgaard), Philipsens og det meste af Paulsens (nu Skansegaarden) er ogsaa hranlt. Da jeg gik hjem, kunde jeg nær vare bleven skudt af en Granatkugie. Den sprang nasten over mig, og et Stykke leraf slog nerl tat verl mig, sar at Dyndet oversprøjtede mig. Jeg var inde hos J. Bonefelit og Svoger hunz paa Hjemvejen. Man skøl fra begge Sider merl Kanoner, fra lynt efter Nr. 2 og fla Nr. 2 efter Iynt, som ogsata fra de andre Skanser efter en Skanse paa Ragebolmark, mellem Ragehal og Iyly\}!øl.

2. - Paaskerlag. Der skydes med Kanoner i I)ag. I Aften, da vi var gaat til Sengs havde de (cle projsiske Soldater) antandt an stor Ild i I'. Petersens Løkke. Vore Piger kom og sagde, at der var Ilrlehranil luer tat verl. Jeg løb derud, men saa straks, hvarl det var. Jeg gik imirllerticl ud ved Dammen, hvor jeg rendte et Bajonet i det ene Find og fik et slemt Stød.

38. I Morges greh de danske an og drev de tysko tilbage. be (Inilkvarteringen) var alle rykket ud, men kon om Middagen igen tilbage. Der brændte igen et Par Steder i Dybbøl (N. Christensens og $\mathbf{H}$. Jahmsens). - Det hedder at Prøjserne igen har inclaget deres Stillinger.

29. - - - - det ser snart ud til et Slag en af Dagene.

31. - Vore Soldater var meget urolige i Aften, de mente de skulde angrilie i Nat. 
31. - Samme Indkvartering. De var meget slemme i Aften, de havde vistnok sviret. Jeg var urede med dem. De slog nogle Vinduer ind i Karlekamret og Mælkekamret, hvor de stjal et lille Stykke Smør. I Nat er der falden mange Skud fra Skanserne.

\section{April.}

1. - Om Efterniddagen fik vi endnu 16 Mand og 14 Heste fra Artilleriet. De gamle er endnu ikke gode, de har ogsaa været i Røgliamret. G. g. d. s m. f. s.

2. - Artilleriet rykkede ud Kl. 5 om Eftermiddagen og Infanteriet om Natten. Der blev skudt meget fra begge Sider om Eftermiddagen og der brændte ogsaa mange Steder paa Dybbøl Mark. - Idag kom alle de Sandbjerger, Fuglsanger og alle de deromkring i Arrest $i$ Kirken, le blev udløste igen den 4de.

3. - Søndag. De (Indkvareringen) kom alle igen om Morgenen; de skulcle have gaaet over ved Hardeshøj, men der blev intet af. Der skydes endnu, især fra prøjsisk Side. L. Nielsens Hus (nu Harald Jahnsens Gaard) brændte om Formiddagen, og i Aften brænder vistnok søncterborg.

4. - I Aften var (ler en af vore, som var beruset og gjorde sig saare grov og vilde slaa mig. Jeg maatte ind til Løjtnanten, for at faa - Fredl.

5. - I Morges kom Artilleriet bort. Foermændene kom ogsaa bort, men der kom andre i Stedet for dem. Den Soldat, som var fuld og grov, faldt af en af Foermændenes Heste og stødte sig slemt.

6. - Ier var mange af dem (Indkvarteringen) paa Skansearbejde inat, og vi matte levere dem det Tøj vi havde tilbage. Vi har leveret til de første, som laa her i Kvarter 2 Jernskovle og en Spade, som ikke kom tilbage, de fik 1 Spade og 4 Skovle, 1 Jern, en med Jern for og to gamle af Træ. - I Aften brænder det igen i Søn(lerhorg.

T. - Det ryger encinu i Sønderborg.

¿. - Der brænilte et Sted i Ragebøl, ogsaa vistnok en Barakke ved Dybbol Mølle. Om Aftenen brændte et endnu i Ragebøl.

9. - Ilug kom vor Indkvartering paa Forpost og vi fik igen omtrent ligesaa mangen af det 53. Regiments 10. Kompagni med 1 Løjtnant og 1 Doktor. Det lader til, at disse er mere rolige.

10. - Søndag. Hele Natten har de skudt med Kanoner. Om Eftermidldagen kom her yderligere 12 Dragoner med 14 Heste, 2 Officerer, 1 Vagtmester og 9 Meninge. - Idag har Prøjserne skudt Dybbøl Molle ned. 
11. - Dragonerne drog bort i Eftermicklag.

12. - Der brændte igen et Sted paa Langhro. Vore kom paa Vagt hen paa Eftermiddagen.

13. - Imorges kom der 14 Heste og 8 Mand af Artilleriot, om Eftermiddagen kom der 4 Heste og 2 Mand til. Den gamle Indkvartering kom bort og vi fik 60 Mand og to Officerer af 15. Regiments 1. Kompagni. - Der er idag brændt flere Huse paa Als.

14. - Idag har de skudt snart rundt om os. Paa Als er idag hrandt Skovfogdens, Rønhave og et Par Sterler efter Søndelborg. Hoffmanns Hus brændte i Formiddags.

15. - Ny Indkvartering, vi fik 50 Mand med to Officerer af 15 . liegiments 4. Kompagni. Skydningen vervarer og har veret meget streng sidste Nat. Der er brændt flere Stecler paa Als, og vist $H$. ostens i Staugaard. Vi har saaet den forste Havre irlag.

16. - Kanonskydningen vedvarer.

17. - Søndag. De skyder endnu, og især i Nat.

18. - Idag kom Infanteriet jort. Der kom 3 Foemman om Morgenen, som droge bort om Formidlagen igen. De har varet her med Baale. Fra imorges tidlig har der været et haardt Slag verl Skanserne. I Aften kom de og sagde at de havde taget Skanserne. Vi fik i Eftermiddags 40 Mand Jægere.

19. - Disse kom bort idag og vi fik 70 Mand Jagere mell 3 Officelel' af 13. Regiments 1. Kompagni. Mathias maatte sirlste Nat til Brobøl med nogle Soldater og i Dag til Graasten med danske Fanger.

20. - Artilleriet med de 18 Heste og Infanteriet ligger her endnu. der kom omtrent 20 Mand bort i Eftermiddags.

21. - Svoger H. Jørgen, Christian og vor Christian var ovre verl vort Sted (Trovshøjgaard) idag. Det var meget ødelagt.

22. - Bededag. Den gamle Indkvartering. De er alle til laalarle for den prøjsiske Konge, Trainkonstablerne ogsaa. I) le kom igen, maatte de straks paa Forpost. Artilleriet kom igen om Aftenen.

23. - I Aften kom der 60 Mand med 2 Officerer af 13. Regiments 3. Kompagni.

24. - Søndag. Jeg var over hos Præsten, for at faa Tillarlelse til at komme til Dybbøl, for at se hvorledes det ser ud.

25. - Ny Indkvartering, 34 Mand og en Officer af 13. Regiments 11. Kompagni. 
26. - Jeg var til Dybbølmark idag,at se mig for. Infanteriet kom bort og vi fik 8 Heste mere af Pionererne med 6 Mand. Tillige fik vi 2 Foermænd.

27. - Artilleriet endnu. Der kom endnu 10 Hestet fra Pionererne.

28. - Ved det Gamle.

29. - Vi fik 30 Mand Infanteri med to Officerer. Jeg var idag til Dybbølmark. Alle vore Brædder var stjaalne.

30. -- Igen til Dybbøl at saa Havre. Vi saaede to Tønder. Hans var

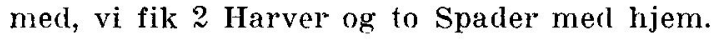

\section{Maj.}

1. - Søndag. Samme Indkvartering.

2. - Jeg var til Egernsund, at høre om Sxelekorn. Der blev mig tilstaaet 15 Tdr. Havre, 10 Tdr. Byg, og 60 Pund Kløverflø. Vi fik 9 Tdr. Havre og to Sække Kartofler med til Broder Jørgen. De Danske har skudt dygtig fra Arnkil og Kjaer over til Sandbjerg efter Pionererne, som kørte Baadene fra Storskoven.

3. - Jeg var igen i Egernsund, men vi fik kun 13 Trlr. Havre i Stedet for 32 Tdr. og saa fik vi ogsaa 40 Pund, 60 Pund og 80 Pund Kløverf'ø. Ilag kom Pionererne bort og Artilleriet ogsaa, men der kom andre Artillerister i Stedet, nemlig 13 Heste med 12 Mand.

4. - Idag kom Infanteriet bort, men vi fik andre 70 Mand med 3 Officerer af 10. Kompagni. - Vi saaede Havre i Nedreløkken idag.

5. - Himmelfartsdag. Vi var i Egernsund efter Havren og vi fik den. (I Tiden fra 5.--12. Maj nævnes ikke noget af særlig Interesse. Hver Dag har de været paa Trovshøjgaard og siaet Havre m. m.)

11. - Indkvarteringen er her endnu, men i Aften tales der om Vaabenstilstand.

12. - Idag kom der nogle af vore Infanterister bort, nemlig 28 Mand. Vi var igen til Dybbøl og kørte Træ og Brædder.

13. - Igen til Dybbøl. Vi kørte vort Egetræ op til Svoger P. Vogd. Om Eftermiddagen harvede vi Byglandet. Idag el Tyskerne næsten. alle marcheret fra Dybbøl.

14. - Imorges marcherede Infanteriet bort.

15 - Imorges marcherede Artilleriet bort. De kastede først vor Kaffemølle og Puster paa Ilden, som jeg meidte til Underofficeren, 
der blev meget opbragt derover. Om Formidalagen kom der igen 3 Mand af 15. Regiment, som skal have Forplejning. Den ene var Sergent.

16. - Idag flyttede P. Vogds til Dybbøl. Vi kom i Kørsel til Aabenraa med en syg.

17. - Vi begyndte at saa Byg; og blev færdig den 18.

19. - Var jeg til Træauktion ved Byllemoses, hvor jeg købte en Uel Træ.

20. - Kørte vi Træ hjem, 18 Læs (til Genopbygning af Gaarden), De følgende Dage blev der saaet Byg i Dybbøl.

23. - Jeg var i Nybøl for at se om en Vogn, som var bleven stjaalen, wen fandt den ikke. - I de følgende Dage blev der arbejdet i I)ybbol.

2\%. - Herredsfogden var hos os (paa Dybbøl) for at taksere og han gik med op til en Marketender, som har mine Brædder. men Manden var der ikke.

De følgende Notitser drejer sig om Landbruget og Forberedelse til Genopbygningen af Trovshøjgaard. Den 8. Juni kom atter 30 Infanterister og 3 Ulaner til Indkvartering. De var "saare stortalende, men ellers flinke«.

\section{Juni.}

12. - I Nat drog vor Indkvartering bort. De har haft saa travlt med at gøre Arrighed i Nat. Saaledes har de slæbt en Vogn op paa Huset og sat en Gryde og en Spand paa Skorstenen, Bryggerkedlen paa Vogne, slaaet nogle Potter itu, revet Vognkurven i Stykker paa Kørevognen og flere Uartigheder, men de var meget beruset.

Notitserne fra Dagene indtil den 26. Juni omhandler hoverlsagelig Arbejdet paa Gaarden i Dybbøl.

22. - Idag kom Tyskerne igen til Bøffelkobbel og lagde dem i Lejr, der kom ogsaa en Del til Blans.

25. - Vi fik idag 29 Mand og en Feldwebel af 64le Regiments 9. Kompagni. I Nat er Vaabenstilstanden udløben.

26. - Søndag. Tyskerne begyndte straks imorges at skyde fra $P$. Nissens Batteri og fra Randersgaard. Vore clrog bort i Middags til andre Kvarterer. Vi fik i Eftermiddags 1 Hauptmann, 1 Løjtnant og 8 Mand Sygebærere, eller Staben for Sygebærere, med 6 Heste, nemlig 4 Officersheste og to Vognheste. De har idag stillet Telegrafen her lidt nordlig forbi. 
27. - Der var stærkt Røre i Indkvarteringen i Aftes, desuagtet har alt været rolig i Nat. I Formiddags fik vi 22 Mand af 35 . Regiments i. Kompagni, de var alle Skippere og samlet fra de andre Kompagnier. Hele Sottrupskov er fuld af Baade og en stor Mængde Artilleri t: forsamlet ved H.P. Skovs. Der vil vist snart ske noget. Vore Infanterister gik i Aften Kl. 8, vistnok paa Arbejde.

2א. - Infanteriet kom først igen Kl. 10 i Formidalags. Det blev dem frielest, at de straks skulde faa dem noget at leve af og derefter gaa til Ro, for at de kunde have Kræfter til i Nat, det vil sige: Gaa los paa Als. -- Lorens var i Krigskørsel til Stenderup efter Sengesterler.

3.). - Ganske rigtig. Vore gik ikke i Seng. Infanteriet drog bort Kl. 12 og Krankentregerne Kl. 2. Tyskerne satte over med Baade og det varede ikke længe inden de var derover og havde Als i deres Magt. Der er vist mange falden og saaret, mange gjort til Fanger. - Jeg val i Mildags nede ved Kysten at se paa Overfarten. Der var fuldt af Artilleri og Kavalleri og alle Vaabenarter, fra Havet til $H$. $P$. Skovs, baade paa Vejen og i Lykkerne ved Siden af; alt Korn og Gras i disse Marker var ørlelagt. I Aften slaar de Bro ved Sønderjorg.

30. - I Morges drog Infanteriet bort, det kom til $\Lambda$ ls, de andre er hor endnu. Alle de døde ligger endnu ubegravede paa Marker omkring paa Als. Om Eftermiddagen var jeg til Sønderborg og h.jenime. I Sønderborg var der næsten ingen Folk foruden Militaret. Der Juænulte et Par Huse der igaar. Hjemme havde man grasset vor ny Kløver af. Inspektøren (fra Sandbjerg), Andreas Paulsen, Jurgen Jepsen, Svendsen, Jørgen Hansen paa Dybbøl Mølle og Johannes Jørgensen ved Sønderborg, som alle var arresteret af Prøjserne og senclt til Flenshorg, kom hjem i Eftermirlag.

\section{Juli.}

1. - Imorges gik jeg til Nørremølle, hvorfra der kom en dobbelt Ligskure, nemlig to af Pionererne, som var faldne. De var smukt smykketle, og hegge Kompagnier, der laa der, fulgte dem med Musik i spidsen. - Morl Aften fik vi 10 Mand af 15. Regiments 12. Kompagni.

2. - I Eftermiddag drog Krankentrægerne bort. Infanteriet kom paa Vagt, men om Aftenen fik vi 30. Mand, en Feldwebel og 3 Underofficerer af samme Regiment og Kompagni.

3. - Søndag. Om Eftermiddagen paa Dybbølmark. De fleste Tropper trækker fra Als, vistnok nordpaa. Her (Snogbæk) ligger for- 
uden Krankentrægere og Lasaretfolkene et Kompagni, og i Dyblogl et, som vistnok er det meste her paa Sundever, foruden Artilleriet.

I Dagene efter 3. Juli er der kun Tale om private Forhold, Lanrlbruget og Opbygningen af Gaarden etc. Den 8 . Juli var cler Forsimling i Skolen, vedrørende Indkvarteringen.

9. - Ilag i Graasten. Da jeg kom hjem var der en Arrestbefaling til mig fra den Hauptmann, der havcle samlet os i Skolen igaar. Jeg skulde nemlig have sagt ham Sandheden for meget, hvorover han er hleven vred. Jeg maatte ned til ham om Aftenen og hlev hragt i Vagten, hvor jeg maatte sidde, til der kom Bud efter Chr. Dall. Han (Officeren) truede med at sende mig til Flensborg. Jeg kan ikkesige, at jeg brød mig stort derom, men min Familie var saare urolig. Da Chr. Dall kom, blev det dog ved en god Gardinprædiken og jeg gik derpaa hjem, glad blev Moder og Børnene.

11. - Til Dybbøøl. Christian og jeg samlede Kløver. Vi kunde ikke holde Foermændene borte fra kløverne om vi entlog var derverl. Vor Indkvartering kom bort, og vi fik ingen igen.

14. - Irlag kom 4 Murmænd foruden Mesteren og begyndte at laggeGrund. I Jesu Christi Navn lad dette Hus staa med det gode og vere til Gavn for mig og min Familie. Gill, at vi ikke endnu en Gangr skal blive husvilde, kære Herre Gud!

Tiden indtil den 20. August gaar med Bygningsarbejde og drbejde i Marken. Gaarden var ved at blive saavirlt færdig, at Familien kuncle komme hjem igen.

\section{August.}

22. - Jeg flyttede Tøj over til Dybbøl og kørte Sand til at lægge Guls: 23. - I Guds Navn lad det gaa os godlt! Idag flyttede vi tilbage til Dybbøl med hele Familien.

Den 22. Oktober skriver Henrik Hansen: Idag fik vi Laden rejst i G. F. N. (= i Gud Faders Navn). Gucl lad den staa til Lykke for mig og mine i mange Aar. _ _. -

Trovshøjgaard, der har sit Navn efter "Trovshøj«, tlen store Langdysse, der laa, hvor der nu er Parkeringsplads paa I)ybloblhanke, staar endnu, som ren blev opført efter Krigen 1864.

Dens gamle Ejer, Henrik Hansen, har med sine jærne Daghogsoptegelser overleveret os et Stykke Hjemstavnshistorie, der er varil at gemme.

\section{Spredte Notitser fra Broager 1864.}

I Arkivet paa Sønderborg Slot gemmes et Ark Papir; skrevet af Kristen Karstensen, "Als Sangen«s Digter, da han i 1864 var Provst 
og Sognepræst i Broager. Notitserne omfatter Tiden fra 6. Februar til 18. Marts 1864.

\section{Februar.}

6. - Ved Midrlagstid modtog vi Lnderretning om vore Troppers Tilbagegang fra Dannevirke.

7. - En Søndag var̆ Landevejen fuld (af Soldater etc.) ad Sønderliorg til. En Løjtnant Jacolssen kom her igennem med en Del Teleglafredskaber og tratte Soldater. De fik den ene af mine Vogne, da den de havde, var gaaet i Stykker.

7.-14. var alt roligt. Tyskerne opkastede Skanser ved Holdnæs og twærs paa den anden Side ved Egernsund. Den 15. toges Færgen og kort efter Fargemanden, som dog Dagen efter kom tilbage. Den 16. oln Aftenen var der en tysk Patrouille I Skodsbøl.

1\%. - Onsdag, henad Kl. 10 blev Pastor Schleppegrel1 ${ }^{\text {) }}$ afhentet og fort til Egernsund (hos Fru Schlaikier) og samme I)ag om Aftenen Jlev Husfoged Bülow og Tingskriver Hansen ligeledes afhentet. De fortes derpaa til Graasten, og siclen til Flensborg, hvorfra de den 22(le hlev frigivne og kom hertil igen ten 23 .

21. - Søndag, var der uniddlelbar efter at jeg havile encl min Konfirmation, Militærgudstjeneste i Kirken; og var der dengang allerede begyndt paa at indrette en Militærtelegraf paa vort Kirketaarn. I denne Anledning blev først 3 store Træer samme Dags Eftermiddag omsavede, og atter næste Dags Formiddag den 22de tre andre.

22. - Mandag, var der en Forpostfagtning, hvori ca. 150 danske (Sydslesvigere) løb over og gav sig fangen. Hvor mange Tyskerne mistede, vides ikke, men en højere Officer i det mindste skal vare falclen.

18. - Stor Idkvartering her, efter at om Formiddagen Esbern Snare ${ }^{2}$ ) havde været inde ved Egernsund og allarmeret. Vi fik 60. Regiment. Staben, Major Stülpnagel etc., laa hos Kancelliraadens. En Hauptmann Caspari etc. laa hos os.

19. - Om Aftenen fik vi 3. Jægerregiment (Bataillon). Stab: Major Witzleben med Østerrigeren Grev Caranini og Lauenborgeren Baron

1) Pastor Julius Carl Gerhard Schleppegrell, født i Slagelse den 17. Novbr. 1811, udnævntes til Diakon i Broager 1. Novbr. og indsattes 28. November 1852. Han blev afskediget den 28. April 1864. Hans Efterfølger vaĩ Pastor L. A. Reuter, + 12. Septbr. 1905.

$\left.{ }^{2}\right)$ Det var ikke "Esben Snare«, men »Rolf Krake« der den 18. Februar var i Frgtining ved Egernsund. 
Bruxelles - hos Kancelliraadens. Hauptmann v. Hennings, Gotha og Leutn. Forstner, Berlin, samt en Læge Grosser af Prenzlau, hos os. - Nu for Tiden skal der i Broager ligge rigelig 1000 Mand.

Løjtnant Hoffmann fra 8. Marts. Den 10. Marts OmkvarterinoMajor v. Stülpnagel, Adjutant v. Stutterheim, Stabslæge v. Asten og Løjtnant v. Kaminitz af 60 . Regiment, hvilke blev hos os til den 14. Marts. da vi fik vor forrige Indkvartering igen.

Paa Broager Mølle laa General v. Castein. Møller Clausen var fiere Gange sat fast, først fordi han lod Møllen gaa, tre Gange, fordi han havde faaet et Brev fra Kongeriget, hvori Tyskerne, og navlig Prøjserne var udskældt for noget Røverpak, som Brevskriveren onsker, Møller Clausen snart maatte vorde befriet for.

\section{Marts.}

15. - Begyndte Bombarderingen fra Dynt Bakke.

17. - Stærk Bombardering og almindelig Udrykning til Bestormning af Skanserne. Flere Gaarde brænder i Dybbøl, formentl. Hans Jahnsen, Tofts og Smedens, ogsaa nede ved Sandbjerg og i Ragehol brændte det. Paul Paulsens Ladebygning brændte ogsaa, Vaaningerne var brændt d. 16. Blodig Fægtning.

18. - Begravedes 5 tyske Lig (Prøjsere).

Videre er Provst Karstensen ikke kommet. Han blev suspenderet og afsattes senere af de prøjsiske Myndigheder (den 28. April 1864). Kresten Karstensen, født den 25. April 1809, Søn af en Gaardejer i Kær ved Sønderborg, var siden 1839 Præst i Dylibøl, hvorfra han udnævntes til Sogneprast i Broager den 6. December 1857, mens han 28. Maj samme Aar var blevet udnævnt til Provst over Sønderborg Provsti og konstitueret Provst over Aabenraa Provsti. - 1865 blev han kaldet til Sognepræst for Gelsted og Rørup Menigheder paa Fyn. Her døde han den 1. November 1882.

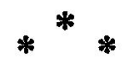

C. H. Clausen, Broager Mølle, (1805-1883), har skrevet sit Livs Frindringer. Her gives et Udtog af hans Optegnelser fra Krigstiden +1864 :

"- - - - Jeg var Lørdag før Faste kørt til Graasten med nogle Breve, hvor jeg hørte at Tilbagetoget fra. Dannevirke var $i$ Gang. Da jeg kørte tilbage mødte jeg paa Vejen til Sønderborg de forste Tropper. Derefter kom de, uafbrudt Dag og Nat. Allerede Lordag Eftermiddag begyndte Beboerne $i$ Dybbøl at bringe deres Indbo og Kreaturer til Broagerland. Fra Christensen i Ragebol fik 
vi 16 Køer og 4 Heste og en Del af Indboet, men kun liclt Foder. Paa denne Maade blev næsten alle Beboere betænkt med Gods og Kreaturer. Ogsaa mange af Beboerne kom herover. Det varede heller ikke længe før Prøjserne var der. Først kom de til Graasten. Den næste Dag slog de en Bro over Egernsund. Til Broager kom (ler først Partouiller, der straks havde et vaagent Øje for Vejrmøllen. ve kaldte min Søn Christian og forbød ham, at ændre noget ved Sejlene paa Vingerne. Endnu samme Dag kom en Officer ridende i Galop foran min Dør og spurgte mig: "Sind Sie ler Müller hier?" Jeg sagde ja. Officeren bad mig straks følge med. Jeg spurgte, om jeg skulde langt med, for saa vilde jeg gerne have Støvler paa. Officeren svarede, at den korte Tid jeg endnu have at leve, kunde jeg godt gaa med Pantofler. "Skal der være Krig, saa lad det være Krig «, svarede jeg, og gik med. Vi kom ud paa en nærliggende Kol,bel, hvor der stod en Afrleling Soldater. Her blev jeg underkastet et Forhør og fik saa Lov til at gaa med den Formaning, at jeg skulde holde mig rolig og ikke ændre noget ved Møllens Sejl.

Da "Rolf Krake engang kom ind i Egernsund ${ }^{1}$ ) liom en Adeling Soldater med ren Ordre, at Møllen øjeblikkelig skulde sipttes i Staa. Sejlene blev skaaren af og taget med.

En Søndag kom en Officer med to Mand ind til mig i Stuen og erklærede, at jeg var hans Arrestant; jeg skulde med til Graasten. Hvis jeg havile en Vogn kunde jeg køre, ellers maatte jeg gaa. Da jog aabnede Køkkendøren, for at sige min Søn Besked om Vognen, raabte Officeren: "De bliver her!" — "Nu ja, hvis De vil", var mit Svar, "men saa kommer vi jo ikke til Grausten". Sluttelig maatte jeg foretage det norlvendige og kørte saa, hevogtet af to Soldater, til Graasten.

I Graasten blev jeg ført frem for Major v. Blunienthal. Han sagde, at der var kommet et Brev til mig, og han bød mig at læse det. Da jeg tog det i Haanden, bemærkede jeg, nja det er fra min Kommissionær i København, som har sendt Penge til mine Søstersønner, der tjener i den danske Har. Blumenthal svarede: "Les videre, stik Brevet i Lommen, og saa skriver De til Deres Kommissionær, at han i denne Tid kun skriver i Forreiningsanliggender, ellers vil Følgen være, at De bliver arresteret, hver Gang De faar et Brev fra ham. Og nu kan De gaa, de to Mand kan gas med, for at De kan komme over Broen (ved Egernsund)«. I det omtalte I3rev havle min Kommissionær udtalt sig meget forbitret over Prøjserne.

Møllen med tilhørende Bygninger og den i Nærheden beliggende Hørfabrik var stærkt belagt med Militær. Først havde vi Jægere og en Major von Witzleben i Kvarter, det varede ikke Iænge. En Dag kom General v. Canstein`s Aljutant og besaa Kvarteret og Staldene,

1) Den 18. Februar. 
som han rekvirerede for Generalen. Generalen kom med sin Stab, den bestod foruden Generalen og hans Adjutant af Kuske, Tjenere, 5 Skrivere, Ordonnantser, Kurerer o. s. v., ialt af 17 Mand.

Denne Indkvartering varede 12 Uger. Jesuclen havde vi i Horfabriken i de forste Uger 100-150 Heste. Sa kom der en hel Artilleripark med 300 Heste med tilhørende Mandskab, en Gang imellem en Ekstraindkvartering af 50-70 Mand. Iblandt Artilleristerne var 4 Sadelmagere og 4 Smede, de var slemme Broule. I laasede lium var Indhoet af de fra Dyblol flygtede Beboere opbevaret, men smedene var frxkke nok til at Irycle Døre op, endskønt det var Jerndore, for at se, om der var noget de kunde lruge. Der blev ogsaa stjaalet Lærred. Der laa meget Brændsel, som de urlen viclere brugte. Dag og Nat havde de Ild, for at kunne vaske, koge o. s. v. Halm og Brændsel hlev ikke leveret, vi matte forsyne Soldaterne dermed, saalænge vi havde noget. Da Brixulselet var ved at slippe op, tog de Brwdder og Maskindele, uden at vi nogensinde har fanet Godtgyrelse derfor.

Generalen var en elskvardig Mand og meget underholdende. Hver Morgen kom han url i Kokkenet og fortalte et og anclet. En Morgen sagde han til min Datter: "Har be allererle hort, at Deies Prast") er lobet bort i Nat?« - "Ja«, svarede hun, "det undrer mig at le med alle Deres Soldater ikke har passet bodlye paas.

Da jeg kom fra Graasten, lykønsketle han mig til, at jeg var bleven saa hurtig fri. For Soldater er det ofte nolvendigt, at vare mistroisk. Jeg sagde, at jeg i denne Tid ikke godt kunde vare læenge hjemme fra, og sorgede derfor at jeg hurtigst kom hjem!

Arljutanten var mere klads og en Gang blev vi uenige. Halmen var sluppet op og vi skar utærsket Hvede til Hakkelse. Knapt var vi færtig dermed, kom Artilleristerne fra Fabriken og hentede den. Jeg henvendte mig til Arljutanten og had ham om at varetage mino Rettigheder, men jeg kom til den forkerte. I Stedet for at finde Stotte hos ham, blev vi meget uenige og skiltes i I'venskib.

Efter at Skanserne var erohrede kom Hans Petersen's Hustru fra Mølmark og anmoderle mig om, at berle Generalen om at satte hendes Mand, der var arresteret paa fri Fod, da han nu dog ’ikke kunde være farlig mere. For nogle I'ger siden vąr hendes Answyning blcven afslaaet. Jeg havole ikke Lyst til at gaa ind til Generalen, da Adjutanten var hjemme, og lod clerfor min Datter gaa ind, men ikke igennem Adjutantens Varelse. Da hun havde forelagt Generalen hendens Anliggende, kaldte han paa Arljutanten og sagde: "Hvad, er Gaardmand Hans Petersen ikke firigivet endnu? Ordren er clog givet for nogle Dage siden!“ - Arljutanten saa lidt bistert efter den Dor,

") Pastor Schleppegrell. som hlev arresteret den 17. Feloruar. 
igennem hvilken min Datter forsvandt, denne Gang kunde han ikke redes paa mig."

Kort efter at Krigen var brudt ud, kom min Søn Jørgen hjem fra Hildesheim. I)a hans Rejsepas først udløb i Januar (1865) blev han ikke indkaldt til dansk Militærtjeneste. Han var og til stor Nytte hjemme. Min Søster, Enkefru Ernstedt havde en Beværtning med et lille Høkeri i Broager, ${ }^{1}$ ) som hun drev sammen med et Par voksne Døtre. Desuden var, kun en Huskarl i Huset. Lokalet var dengang det største $\mathrm{i}$ Byen og det besøgtes meget af Militiret. Broager var (len eneste By i Nærheden af Dybbøl, hvor Soldaterne kunde faa Forfriskningel. Hver Dag var Huset fuldt, til Tider kom der 24 højere Officerer til Aftensmad, ligeledes Feldwebler og Underofficerer, som vilcle have valm Mad. Det var ikke altid saa let at tilfredsstille den, da vore Vogne næesten altid var paa Krigskørsel. Undertiden var let ikke muligt, at faa $\emptyset \mathrm{l}$ og andre Varer hentet fra Flensborg. Folan Huset stod en Række Sten, forbundne med Jernkæder. Derfor blev den af Soldaterne kaldt »der Ketténkrug" (= "Kædekroen«).

Jørgen hjalp ved Betjeningen. Det varede ikke længe, før Soldaterne havde laxt en god Grog at kende og yndede den meget. Naar Glassene ikke var helt fulde, protesterede de. Jørgen løb saa med Tablettet url i Køkkenet og fyldte Vand til, og Soldaterne var tilfjerlse. - -

H. Mahler beretter i $\sin$ „Kriegstagebuch" on »Kædekroen« i Isoager. Han skriver om den smukke Gæstgivergaard med de propre Gxstestuer. Lokalet til venstre bar Paaskriften med Kridt "Grena¿lier-Ressource», til højre "Officers-Ressource». Her drak Majoren sit Glas. her kom Mp. Hartmann fra »Times«, Maleren Günther, Tegneren for "Illustr. Zeitung", "lleber Land und Meer" ng "Gartenlaube«. - - -

1) Nu Central Hotellet. 